\title{
Corrections and Short Notes on my Papers
}

\author{
O. B. SHEYNIN \\ Communicated by C. TruesDeLL
}

I have published thirteen papers in this Archive and some correction of almost all of them is overdue. In what follows, I take up these articles, one by one, note the mistakes and misprints, and point out references which should have been noticed before. It is almost self-explanatory that any review of the literature which appeared meanwhile is out of the question. I append an index of names mentioned and an index of subjects.

Notation. Roman numerals denote my papers. A reference such as [ii; 17$]$ indicates reference [17] from paper [ii]. Except for expressions "Replace [3] by [6]", [1], [2] etc. stand for items [1], [2] etc. in the list of references appended to these Corrections. Finally, 1.3b (or $2 \mathrm{~b}$ ) etc. denotes line 3 (or \& 2) from the bottom of the page while an arrow means "see (also) my contribution."

\section{Newton and the Classical Theory of Probability}

(this Archive, vol. 7, No. 3, 1971) [i]

1. p. 218 , middle. Halley and geometric probabilities $\rightarrow[x$, p. 228].

2. p. $221,1.8$. Arc measurements: I mean meridian arc measurements.

3. p. 224, middle. The proof is not given by Newton: in a letter dated 1972 Professor D. T. WHITESIDE commented: ... the proof does exist in an unpublished MS and is more elementary than yours, viz. ... . He also added: ... your immediately following inference that Newton's phrase 'motus regressus' is an 'astronomical expression' - I cannot admit.

Regarding my § 1.3, WHITESIDE noted: NewTON in fact (but not in explicit statement) had a precise understanding of the difference between random and structurally 'inbuilt' errors. He was certainly, himself, absorbed by the second type of 'inbuilt' error, and his many theoretical models of differing types of physical, 
optical and astronomical phenomena were all consciously contrived so that these structural errors should be minimized. At the same time, he did, in his astronomical practice, also make suitable adjustment for 'random' errors in observation ... . 4. p. 227, just above $\S 2.1$. Mean statistical values: In a letter dated 1971 Professor E. S. PEARSON opined:

From reading [the Lectures on the history of statistics], I think I understand what K. P. [PEARSON] meant when he referred to Newton's view of the deity, who maintains mean statistical values ...; he has stepped ahead of where Newton had got to, by stating that the laws which give evidence of Design, appear in the stability of the mean values of observations, i.e. [he] supposed Newton was perhaps unconsciously thinking what De Moivre put into words.

5. p. $228, \S 2.2 .1$. ARBUTHNOT $\rightarrow$ [iv, §5].

6. p. $231, \S 2.3,1.3$. BoYLE's lectures: BoYLE's will is published in his Works [5, p. clxvii].

7. p. $238, \S 3.1$. LAMBERT $\rightarrow$ [ii, pp. 245-246].

8. pp. $240-241$. Statistical method in biology $\rightarrow$ [xiii, $\S 5.8 .1]$.

9. p. $241, \S 3.3$. ARISTOTLE $\rightarrow$ [vii, § 2.2].

\section{J. H. Lambert's Work in Probability}

(this Archive, vol. 7, No. 3, 1971) [ii]

10. p. 246, I 4b. LAMBERT's reasoning: Cournot [xiii; 51, pp. 57-58] and then Chuprov [xi ; 61, p. 188] noticed it. Note its relation with the concept of a normal number.

11. p. $248,1.2 \mathrm{~b}$. Number of children in adjusted data: LAMBERT likely allowed for those who died in childhood.

12. I cite another passage from Professor PeARson's letter (see item 4):

Curiously, I find no reference to Lambert in these lectures [on the history of statistics]. It was not because his writings were in German of which my father was an excellent scholar. I suppose, however, that he selected the names of the personalities he would study from a limited number of sources, e.g., Todhunter, and that these did not include Lambert's name. [TODHUNTER did refer to LAMBERT, but failed to describe his work.] Of course, ${ }^{*}$ K. P. [PEARSON] was over 70 by the time his history lectures passed the year 1750, and no doubt his exploration was limiting itself to the four Frenchmen, Condorcet, D'Alembert, La Grange and Laplace.

\section{On the Mathematical Treatment of Observations by L. Euler}

$$
\text { (this Archive, vol. 9, No. 1, 1972) [iii] }
$$

13. p. 48, 1.3 after formula (4). Weighing of observations: LLOYD studied estimators with weights depending only on the order of the corresponding observations.

14. p. 48 , I $2 \mathrm{~b}, 1$. 6. Posterior estimators: the first to use them was SHORT, not PINGRÉ [iii, p. 48, note 17]. 


\section{Finite Random Sums etc.}

(this Archive, vol. 9, No. 4/5, 1973) [iv]

15. p. 276, T 2. Dice with unequal numbers of faces not considered after MoNTMORT: this should not imply that the behavior of random sums was not studied in the most general case.

16. p. 287 , I 3 b. Independence of events (observations) $\rightarrow$ [vi, p. 112, ๆ 3 ; viii, p. 172,1 . 10 before $\S 3$; ix, p. 11, lower half of].

17. p. 293, footnote. Discontinuity factors $\rightarrow$ [ix, p. 1, note 1$]$.

18. p. 294, 1.9b. LAPLACE's understanding of continuity of functions: he did follow the generally accepted views of the time.

\section{R. J. Boscovich's Work on Probability}

(this Archive, vol. 9, No. 4/5, 1973) [v]

19. p. $306, \S 1,1.3$. For a description of BoscoviCH's geodetic work see ČUBRANIČ [6].

20. p. $307, \S 1.1$, title. Arc measurements: see item 2 .

21. p. 310, lower half. Adjustment of observations by LAPLACE $\rightarrow$ [ix, p. 41, footnote].

22. p. 312, solution of equations (1.3.2) $\rightarrow$ [xii, p. 33].

23. p. $312,1.6$ et seq. Number of exactly satisfied equations: Before one of BosCovicH's restrictions (sum of errors equals zero) was allowed for, system (1.3.2) involved four unknowns. Its solution led to three equations that should be satisfied exactly. This fact corroborates Gauss's conclusion [v, p. 311, 1. 2b] which I previously did not believe in. Even before my paper [v] appeared in print, I had informed Professor R. L. PLACKeTT of Gauss's “error" and he incorporated my incorrect remark in his own article [ix; 63, p. 242].

Professor S. M. STIGLER who pointed out my mistake (letter dated 1981) added: Gauss's last sentence [v, p. 312, 11. 1-2] puzzles me (what does "before" refer to?) but your suggested change (ibidem, 11.8-9) seems wrong to me.

24. p. $316,1.4$. Replace $\left(a_{i j}\right)$ by $\left(a_{j i}\right)$.

\section{Mathematical Treatment of Astronomical Observations etc.}

(this Archive, vol. 11, No. 2-3, 1973) [vi]

25. p. 98, § 2.1. I should have included a subsection on Levi Ben Gerson [13, $14,23]$.

26. p. $108, \S 3.3$. Falsification of observations: BABBAGE published a short account [2] exposing various methods for falsifying observations.

27. p. 115 , a passage from BRADLEY. I note a similar opinion of DESCARTES [7, p. 48]: ... je remarquais, touchant les expériences, qu'elles sont d'autant plus nécessaires qu'on est plus avancé en connoissance ... . 
28. p. 119, 11. 2-3 under Table 2. Mittlerer Betrag recht und schlecht: The original Latin expression ex aequo et bono actually means in fairness and justice. This correction is due to Professor N. SwERDLow who expressed his view in a letter to Professor W. KRUSKAL. The letter dated 1979 contains a phrase feel free to send copies around. SWERDLow disagrees with my interpretation of KEPLER's treatment of observations [vi, p. 119]. He rather agrees with J. J. FilLIBEN. Rejecting the most deviating observation and assuming double weight for the middlemost observation, the latter arrived at the same estimate as KEPLER (and myself). However, EIsEnhart [9, p. 356], who quoted FilLiben and referred to Professor O. GINGERICH, proved that the problem is rather complicated.

29. p. 119, lower half. An English translation of Bodinı's book was published in 1606 and reprinted in 1962 in Cambridge (Mass.). The relevant portion of the book occupies pp. 781-792 of the reprint.

30. p. 120, first passage from KEPLER $\rightarrow$ [ix, p. 49, note 12].

31. p. 120, last passage from KEPLER. Statistical procedures connected with coining money deserve special attention [31, pp. 79 and 81; 29].

32. That the errors of TYCHONIAN observations did not exceed $8^{\prime}$ (p. 120) was my misunderstanding; actually, the accuracy of these observations, as KEPLER stated, enabled him to distinguish errors of 8 '.

\section{On the Prehistory of the Theory of Probability}

(this Archive, vol. 12, No. 2, 1974) [vii]

33. p. 97, note 2a. Schiller on randomness $\rightarrow$ [xiii, p. 330, note 15].

34. p. 102, 1. 1. SAMBURSKY quotes Simplicius: In a reprinted version of his article [x; 117], SAMBURSKY amended his reference to Simplicius. Elsewhere [24, pp. 55 and 97-98] he supplied related information on LeUCIPPUS, AleXANDER APHRODISIENSIS and Chrysippus.

35. p. 104, 1. 3. Chance and production of females: according to VAN BRACKEL [x; 103, p. 125] ARISTOTLE considered phenomena with logical or subjective probability less than 0.6-0.9 to be accidental. VAN BRACKEL's criticism (ibidem, p. 120) of my article [vii] or at least of its first sections seems to be correct.

36. p. 105, 1. 8. A moral law of large numbers: $c f$. RabiNoviTCH [22].

37. p. 107, middle. Ordeals were cooked-up frauds: this was the opinion of TYLOR [32]. He asserted that the rate of "success" was $50 \%$.

38. p. 109, note 55. Quantification of qualitative characteristics $\rightarrow[x, p .217$, end of footnote].

39. p. 111, passage from Cantor. Joan Gadol (see my note 59 on p. 110) rather than I noticed this passage.

40. p. $112,1.6$. Complexity of games of chance: An appropriate example is the game of the bowl, the principal game of hazard among the northern tribes [of Indians] [26, pp. 85-87]. See also Longfellow's Hiawatha, chap. xvi.

41. p. 113, end of note 69. Accusation of gambling: see also Buffon [viii; 9, pp. 67-69]. 
42. p. 114, middle. KEPLER's expression unmathematische Glückspielmethode: SCHNEIDER [25, p. 56, note 32] maintains that this expression (a translation from the original Latin) is unglücklich und irreführend. [Discussing successive approximations in algebra, Wallis [35, p. 254] used the term Stochastick Process]. 43. p. 130 , ๆ 1 b. Section 8.2.1 should be 8.1.2.

44. p. 131, 1.2. All planets return to their position at the moment of creation: according to ancient belief, this event would have brought about the end of the world $[15$, p. $440 ; 34]$.

45. p. $135, \S 9.2,1.2$. An argument about randomness and necossity: the first such argument is due to Nicolaus I Bernoull and De Morvre rather than to KANT [iv, p. 303].

46. p. 137, text between formulas (1) and (2). The reference to KEPLER should be $\S 8.1 .2$ (cf. item 43); as to CARDANO, the reference should be to his Book on games of chance [vii, note 57 ].

47. p. 138, 9 3b, 1. 3. Limit theorems and the paradox of the heap $\rightarrow$ [viii, p. 162, footnote].

\section{P. S. Laplace's Work on Probability}

(this Archive, vol. 16, No. 2, 1976) [viii]

48. p. 139 , just before $\S 2$. New reference: I failed to mention that LAPLACE published a short announcement on the forthcoming publication of the Thér. anal. prob. (Conn. temps pour 1815 (1812), pp. 215-221).

49. p. $141,1.3$ before $\S 2.2$. Change [32] for [17].

50. p. 159, the population of France: BERTILLON [3] published the Résultats sommaires des recensements in European countries. On p. 30 he presented the figures for France throughout the $19^{\text {th }}$ century.

51. p. 161, 1. 1. Include missing reference [viii; 45].

52. p. 172, ๆ 2 before $\S 3,1.2$ b. Replace “independently" by "independent".

53. p. 172. A line which should have been $1.6 \mathrm{~b}$ is missing. It reads: of his scientific career ([39], p. 144; [32], [33]). They were undoubtedly

54. p. 173. Note* should have been placed before the first table.

55. p. $173, \S 3.2,1.2$. Replace ([39], p. 145 and [43], p. 132; [79], p. 296) by ([39], p. 145 and [44], p. 296; [79], p. 132, note 146).

56. p. 177 , 3 . The epigraph referred to is the one to this article [viii].

57. p. 175, 1. 4b. Mean interval between molecules: GiLlispie [12, p. 438] noted the introduction of this concept by PoIsson.

58. p. 175, note *. Introduction of delta function $\rightarrow$ [xi, pp. 250-252].

59. p. $179, \S 4.2$. I should have referred to my earlier contribution [iv, pp. $300-$ 301] where I compared LAPLACE's main work with a monumental maze.

60. p. 184 , Note on HuYGENS $\rightarrow[\mathrm{x}, \S 4]$.

61. p. 186, ref. [42]. This should have been to LAPLACE's Sur les comètes [xii; 95].

62. p. 187. Ref. [80] is missing. My contribution [ix] is meant.

63. p. 187, ref. [81]. The volume of the Hist.-math. essays is 20 rather than 2. 


\section{Laplace's Theory of Errors}

(this Archive, vol. 17, No. 1, 1977) [ix]

64. p. 2, 1.2 above $\S 2$. Delete 'my' from 'my earlier investigation'.

65. p. 5, unnumbered equation after formula (2.2.2): this should be

$$
\varphi(x)=\frac{m}{2} e^{-m(x-v)} .
$$

66. p. 5, formula (2.2.3). In LAPLACE'S original memoir (not in the GEuvr. compl.) the denominator in the formula was 3.

67. p. 39,1 . 3. Measuring angles of a triangulation $\rightarrow$ [xii, p. 50, note 46].

68. p. 45 , note 11. LAPLACE's azimuths: their use in the adjustment of triangulation presupposes the knowledge of the deviations of the vertical.

69. p. 50, 11. 4-2 above $\S 11$. The end of the phrase must read: ... associated with the estimation of the precision of observations (for example, with the study of the stochastic behavior of $L$ ) become extremely complicated for integer $m>1$ as compared with the case etc.

\section{Early History of the Theory of Probability}

(this Archive, vol. 17, No. 3, 1977) [x]

70. p. 210. after $\$ 2$, UlPianus's table: SENTEMANN [27, p. 252] maintained that ULPIANUS based his table on moral and legal considerations rather than on statistical data.

71. p. 212, just before $\S 2.3 .3$. Insurance societies: BabBaGe [1] described the conditions for life insurance stipulated by the main insurance societies of the day.

72. p. 212 , note 2 . Compound interest adversely influenced life insurance: HEYDE \& SENETA [xiii; 73, p. 37] refute this thesis.

73. p. 217, just before $\S 2.4 .2$. New reference: ProukHa [21] studied the work of Petty, Graunt and Halley.

74. p. 223, middle. Quotations from the Logique de Port-Royal: these are from pp. 355 and 372 .

75. p. 229, end of note 1. T. PAINE and his pension program: In a letter dated 1977 Professor W. KRuSKaL remarked:

... there were many pieces of then-published evidence that Paine might have used; the puzzles are (1) why he did not, (2) why his many critics did not pick at that weak spot (weak both methodologically and in terms of estimated cost for the proposed pension program), and (3) why Richard Price wasn't consulted to set Paine straight.

76. p. 240 , 9 I 3 and 6 . The work of Huygens: In a letter dated 1981 Dr. O. ReIERsøL objected to my phrase Huygens ... only describes expectation and noted that I did not give any indication of how HuYGens proved most of his propositions. [On this p. 240 I wrote that HuYGENS directly calculated the expectations sought.] 
REIERSøL argued that HUYGENS proved theorems about, rather than described, expectation [exactly so] and that he, REIERSøL [x; 85], offered a possible explanation of HuYGENS's method. A recent study of HuYGENs's work in probability is due to Freudenthal [11].

77. p. 241, formula (4.1.1). Its correct explanation is due to REIERSøL himself $[x ; 85]$. He informed me of this fact in a letter dated 1980.

78. p. 241, 11. 5-6. Interpretation of HUYGENS's problem: in the same letter REIERsøL objects to the interpretation of this problem, as solved by HUYGENs, in terms of conditional probabilities.

79. I have referred to games of chance indirectly [x, pp. 222-223, first few lines of $\S 2.4 .4$ and p. 223 , note 1$]$.

\section{S. D. Poisson's Work in Probability}

(this Archive, vol. 18, No. 3, 1978) [xi]

80. p. 271 , note 25 , 2 . Mean interval between molecules: see item 57 .

81. p. 279, formula (5.2.2.3). As given by PoISsON himself, the coefficient is $2 / \sqrt{\pi}(\operatorname{not} 2 / \pi)$.

82. p. $289, \S 7.1,1.3$. Change $\S 3.2 .2$ to $\S 3.3 .2$.

83. I long ago decided to restrict my research in probability theory to events which happened before the middle of the $19^{\text {th }}$ century (with, possibly, occasional forays into alien territory).

\section{C. F. Gauss and the Theory of Errors \\ (this Archive, vol. 20, No. 1, 1979) [xii]}

84. p. 33, footnote 17. GAUSS and linear programming: see item 23 .

85. p. $38, \S 4.4$. The death of the probable error: astronomers used the probable error until recently and may be still use it once in a while. It is therefore opportune to quote L. STRUVE [30, see Thesen on the last (unnumbered) page]: Statt des wahrscheinlichen Fehlers sollte allgemein der mittlere Fehler ... benutzt werden.

Note another of his theses (ibidem): Die Anwendung sechs-und siebenstelliger Logarithmentafeln in den Schulen sollte verboten werden.

86. p. 44, just before $\S 5.7$. Substantiation of least squares: In a letter dated 1979 Professor W. KRUsKal writes:

Despite the comments of ... and others, I am not wholly persuaded that Gauss published a full statement of what you call the third substantiation, that is (roughly speaking) least squares as minimum variance estimation, given linearity and unbiasedness of estimator.

87. p. 48, T 2. Role of MARKov: NeYMaN [20, p. 228] subsequently admitted the confusion to which he unwittingly contributed by attributing to Markoff the basic theorem on least squares. 
88. p. 51. Observations in triangulation: one of the leading Soviet statisticians, the late Professor L. N. Bolshev, attempted to study this topic from the vantage point of modern statistics. I do not know whether he had time to complete his research, but at least we discussed the historical aspect of the problem. BoLSHEV thought that GAUss was in favor of attaining a (formal) equality of the variances of the observed angles or directions. I disagreed and subsequently formulated my opinion in this article [xii, p. 51] but my highest respect for BoLSHEv's scientific expertise obliges me to report his point of view. For the same reason I make known a finding of his which I was unable to confirm: one of the geodetic volumes of GAuss's Werke, Bolshev asserted, contained an example of the chi-squared distribution.

BOLSHEV read my papers and told me he understood them (no doubt, a polite reference to errors and ambiguities) and considered them useful; moreover, he corrected a few of my early MSS. For what unsubstantiated evidence is worth, I recall BoLSHEV's words: It was after reading your article [vii] that I came to understand [the statistical aspect of] the work of Kepler.

89. p. $54, \S 6.5$. GAUSS as the master of experimental science: I should have referred to HERMANN [16].

90. p. $56, \S 7,1$, ๆ 3,1. 1. Replace [47] by [46].

91. p. 61, 2. Introduction of word statistics into English: see also HiLTs [xiii; 73a, pp. 24-25].

92. p. 67, Acknowledgements. Replace D. H. L. Harter by Dr. H. L. Harter. 93. Article as a whole: At the time, I could not have known about other contributions on the same subject $[28,33]$ published somewhat before mine.

I did not refer to one of Dr. C. EISENHART's unassuming contributions [8] (which I mentioned elsewhere [ix; 42]). I did not then realize that

(1) EISENHART was one of the first Western authors to present a correct view of GAUss's work in statistics;

(2) The large number of references in my paper [xii] made any omission unduly significant.

EISENHART also published a biography of GAUSS [ix; 43]. It was all but unavailable and at the time $I$ had not seen it since 1975 and did not dare to refer to it once more. It is now reprinted [10].

(1) It was not my intention to discuss Gauss's linear model. On my p. 44 I referred in this connection to IDELSON [xii; 79, chap. 5] and SEAL [xii; 123] and I can additionally mention HELMERT [xii; 75]. I always thought that such authors as HELMERT and IDELSON had adequately described all GAUSs's achievements in this direction though of course not in the language of modern statistics.

\section{On the History of the Statistical Method in Biology}

$$
\text { (this Archive, vol. 22, No. 4, 1980) [xiii] }
$$

94. p. 329 , 1. Recherches statistiques etc: volume 5 appeared in 1844 , fourteen years after Fourier died.

95. p. $336, \S 3.2 .1,11.5-6$. Chance is ignorance of causes: LAMARCK repeated this statement elsewhere [xiii; 91, p. 329]. 
96. p. 343 , note $38,1.3$. Replace "who most possibly also decided" by "who likely took a too resolute point of view".

97. p. 361 , note $71,11.2-1$ b. Herschel referred to SwIFT: so he did $[17$, p. 63 , footnote]: the philosopher's plan for writing books ... has a close parallel in the ... theories of the production of ... animals by natural selection. BAER was not the only one to present a narrow view on evolution!

98. p. 361, § 5.8.1. The Biometric school: $c f$. MACKenzIE [18; 19, pp. 82-91]. The latter source contains chapters on Galton and K. PEARSON, and on the development of the statistical theory.

99. p. 363, 1. 2. Reference to PeARSON: replace [107, p. 321] by [106, p. 321].

\section{On the History of Medical Statistics}

(this Archive, vol. 26, No. 3, 1982) [xiv]

100. $\S 1.2$, end of note 4, Addendum: Mendelsohn [19a, p. 204] testified to the fact that medical probabilities came to become acknowledged, at least for some time: Diese Art von Wahrscheinlichkeit, da wir das Verhältnis der Fälle selbst, erst durch einen wahrscheinlichen Schluß suchen müssen, nennet Rüdiger [De sensu veri \& falsi] die medicinische Wahrscheinlichkeit, weil man in der Heilungskunst aus dem Verhältnisse derer, die an einer gegebenen Krankheit gestorben, oder durch ein gewisses Arzeneymmittel genesen sind, zu der Zahl derjenigen bey welchen dieses nicht erfolgt ist, auf die Wahrscheinlichkeit in einzelnen vorkommenden Fällen schließt ... .

A. RüDIGER's (RIDIGERI's) book was published in 1741 in Leipzig; see Brit. Mus. Cat.

Acknowledgements. Professor S. M. STIGLER advised me to compile an Index, and items 13, 18, 23, 65 and 66 are due to him. Professor K.-R. Biermann noticed a mistake now pointed out in item 90. Professors G. Cohen, W. Kruskal, E. Seneta and S. M. Stigler have sent me xerox copies of some sources to which I refer in these Corrections.

\section{References}

1. Babbage, C., A comparative view on the different institutions for assurance of life. London, 1826.

2. Babbage, C., Of observations. Annual Rept Smithsonian Instn for 1873 (1874), 187197.

3. Bertillon, J., Des recensements de la population etc. Paris, 1890.

5. BoYle, R., Works, vol. 1. London, 1772.

6. C̆ubranić, N. Geodetski rad R. Bošcovića. Zagreb, 1961 ; Geodätisches Werk R. Bošković's. Actes symp. intern. Bošković 1961. Beograd, 1962, 169-174.

7. Descartes, R., Discours de la méthode. Euvr. choisies. Paris, Garnier Frères, s.a., $1-59$.

8. Eisenhart, C., The meaning of 'least' in least squares. J. Wash. Acad. Sci. vol. 54, 1964, 24-33. 
9. EISENHART, C. [Discussion of invited papers on the history of statistics, $40^{\text {th }}$ session Intern. Stat. Inst. (1975)]. Bull. ISI, vol. 46, No. 2, 1976, 355-357.

10. Eisenhart, C., C. F. Gauss. Intern. Enc. of Statistics, vol. 1. New York-London, 1978, 378-386. Orig. publ. in 1968.

11. FreUdenthal, H., Huygens's foundations of probability. Hist. math., vol. 7, No. 2, 1980, 113-117.

12. GILliSPIE, C. C., Intellectual factors in the background of analysis by probabilities. In: Scientific change. Ed., A. C. CrombiE. New York, 1963, 431-453.

13. Goldstein, B. R., Theory and observation in medieval astronomy. Isis, vol. 63, No. $216,1972,39-47$.

14. GoldSTEIN, B. R., Levi ben Gerson: instrumental errors and the transversal scale. J. hist. astron., vol. 8, No. 2, 1977, 102-112.

15. Grant, E., N. Oresme etc. Arch. hist. ex. sci., vol. 1, No. 4, 1961, 420-458.

16. Hermann, D. B., Some aspects of positional astronomy from Bradley to Bessel. Vistas in astron., vol. 20, No. 1-2, 1976, 183-186.

17. Herschel, J., Sun [lecture delivered in 1861]. In: Familiar lectures on scientific subjects this being a collection of Herschel's essays. London-New York, 1866, 47-90.

18. MacKenzie, D. A., Arthur Black etc. Biometrika, vol. 64, No. 3, 1977, 613-616.

19. MacKenzIE, D. A., Statistics in Britain, 1865-1930. Edinburgh, 1981.

19a. Mendelsohn, M., Über die Wahrscheinlichkeit. Philos. Schriften, T1. 2. Berlin, 1761, 189-228.

20. NeYman, J., Lectures and conferences on mathematical statistics and probability. Washington, 1952.

21. Ptukha, M. V., Essays on the history of statistics in the $17^{\text {th }}-18^{\text {th }}$ centuries. Moscow, 1945. In Russian.

22. Rabinovitch, M. L., A $15^{\text {th }}$ century "law of large numbers". Isis, vol. 65, 1974, 229-238.

23. Rabinovitch, N. L., Early antecedents of error theory. Arch. hist. ex. sci., vol. 13, No. 4, 1974, 348-358.

24. Sambursky, S. [Selection of texts, intro. and edition by]. Physical thought from the Presocratics to the quantum physicists etc. London, 1974.

25. SCHNEIDER, I., Wahrscheinlichkeit und Zufall bei Kepler. Veröff. Forsch. Inst. Geschichte Naturwiss., Technik, Bd. A 187, 1977, 40-63.

26. SchoOlcraft, H. R., Oneota. New York-London, 1845.

27. SentemanN, K., Ulpianus als Statistiker. Jahrb. Gesetzgebung, Verwaltung $u$. Volkswirtschaft, Jg. 31, 1907, 247-258.

28. Sprott, D. A., Gauss's contributions to statistics. Hist. math., vol. 5, No. 2, 1978, 183-203.

29. Stigler, S. M., Eight centuries of sampling inspection: the trial of the pyx. J. Amer. stat. assoc., vol. 72, No. 359, 1977, 493-500.

30. Struve, L., Bestimmung der Constante der Praecession etc. Mém. Acad. imp. sci. St. Pétersbourg, ser. 7, t. 35, No. 3, 1887, separate pag.

31. The De Moneta of N. Oresme and English mint documents. London a.o., 1956. This contains $A$ treatise on the new money, 65-81, orig. written in Latin ca. 1280.

32. TyLor, E. B., Ordeals and oaths. Proc. Roy. Instn Gr. Brit., vol. 8, 1875-1878 (1879), 152-166.

33. VAN Der Waerden, B. L., Über die Methode der kleinsten Quadrate. Nachr. Akad. Wiss. Göttingen, Math.-Phys. K1., 1977, No. 8, 75-87.

34. VAn Der Waerden, B. L., The Great Year in Greek, Persian and Hindu astronomy. Arch. hist. ex. sci., vol. 18, No. 4, 1978, 359-383.

35. WALLIS, J., A treatise of algebra. London, 1685. 